\title{
PAPWORTH VILLAGE SETTLEMENT - A UNIQUE EXPERIMENT IN THE TREATMENT AND CARE OF THE TUBERCULOUS?
}

\author{
by \\ LINDA BRYDER*
}

\section{INTRODUCTION}

Papworth Village Settlement, founded in 1917 by Dr (later Sir) Pendrill Varrier-Jones, its administrator until his death in 1941, consisted of a hospital and sanatorium where patients in all stages of tuberculosis were received and treated, and a "settlement" where "ex-patients"' lived with their families in a rural environment and were employed in industries at trade union rates of pay. Widespread praise was given to Papworth throughout its existence ${ }^{2}$ as a unique experiment and to VarrierJones as an original thinker. It was described by The Times in 1927 as "the most successful socio-medical experiment of our times":

The word "experiment" has been used, but the experimental stage has long since passed, and there remains a proved method of the treatment of the tuberculous which is highly successful.... The outstanding features of this settlement for the tuberculous are so surprising as to be almost unbelievable.... A Utopian dream, you would have said, and eight years ago you would have been right; but today Papworth stands as a living example of the success of an undertaking inspired by high ideals, realized in practice... . That there should be more Papworths in this country is not open to doubt. ${ }^{3}$

Successive Ministers of Health of differing political affiliations praised it: Dr Addison, Sir Alfred Mond (who described it in 1921 as "unique and the most wonderful of its kind in the world"4), Neville Chamberlain, Arthur Greenwood, and Sir Kingsley Wood. Sir George Newman, Chief Medical Officer to the Ministry of Health from 1919 to 1935 , described it in 1939 as an excellent and forward-looking institution which had led the way, both at home and abroad, and as "an example of a complete scheme for dealing with tuberculosis, the principal social disease of our time". In 1927, Sir Frederick Milner referred to it as "the most remarkable institution in the country". ${ }^{6}$ Dr R. Brunon of France wrote in 1925, "It represents, perhaps,

*Linda Bryder, MA, Nuffield College, Oxford OX1 INF.

\footnotetext{
${ }^{1}$ Ex-patients is here placed in inverted commas, for Varrier-Jones did not believe that tuberculosis could be cured and therefore still regarded those in the Settlement as patients.

${ }^{2}$ Papworth Village Settlement was a tuberculosis settlement until 1957, when it was broadened to become a settlement for handicapped people in general, as it still is today. The hospital and settlement sides of the scheme separated when the National Health Service was introduced in 1948.

${ }^{3}$ The Times, 8 July 1927.

- Manchester Guardian, 27 July 1922.

${ }^{3}$ George Newman, The building of the nation's health, London, Macmillan, 1939, pp. 415, 417.

- Optimist (a Papworth journal), July 1929, 4.
} 


\section{Papworth Village Settlement}

the greatest progress of the twentieth century", ${ }^{7}$ and the President of the Canadian Tuberculosis Association said that Papworth was "the most important international demonstration of anti-tuberculosis work at present being carried on anywhere". ${ }^{8}$ The Lancet called Papworth in 1940 "the most comprehensive single effort to deal simultaneously with every aspect of the tuberculosis problem". 9

The founder and administrator of Papworth, Varrier-Jones, was recognized in 1922 as a "pioneer in the modern treatment of phthisis [pulmonary tuberculosis]". ${ }^{10}$ After qualifying as a doctor in 1910, he had undertaken research into tuberculosis at Cambridge University. He was appointed acting Tuberculosis Officer for Cambridgeshire in 1915, a post which he combined with his medical superintendence of Papworth until 1920. In 1931, he was knighted, and his obituary in the Lancet in 1941 described him as "a leader in tuberculosis thought". ${ }^{11}$ In the preface to Varrier-Jones's collected works, published in 1943, Lord Horder considered why tuberculosis had not yet been brought under control. He wrote, "The answer to the enquiry is given in this small book, which testifies to the clear thinking and genius for action of Varrier-Jones, a man who did see the problem of tuberculosis and see it whole." 12

The late nineteenth century had witnessed the emergence of a new type of medical institution, the tuberculosis sanatorium. Throughout most of the nineteenth century tuberculosis patients had been largely ignored or relegated to Poor Law institutions; tuberculosis had been regarded as an inherited, constitutional disease over which medicine had little control. However, in 1848, a German doctor, Hermann Brehmer, argued that tuberculosis was curable and later claimed very successful results from the open-air or sanatorium treatment practised at the institution he established at Goerbersdorf in Silesia in 1859. Under his inspiration, similar institutions were set up elsewhere. The discovery of the tubercle bacillus (Micobacterium tuberculosis) by Robert Koch in 1882 gave the movement further impetus. Now that tuberculosis was supposedly brought into line with other infectious diseases, there developed a more positive attitude towards its treatment. Even those who had no faith in Brehmer's open-air treatment believed that the discovery of a cure was imminent. Indeed, Koch claimed to have discovered a cure in tuberculin (a culture of the tubercle bacillus) in 1890. Although this was later discredited, bacteriological experimentation continued alongside the enthusiasm for sanatorium treatment. In 1886, there were nineteen hospitals specializing in tuberculosis treatment in England and Wales; by 1920, there were 176 institutions described as sanatoriums or consumption hospitals in England and nine in Wales. ${ }^{13}$

\footnotetext{
7 Dr R. Brunon, 'Causes, prophylaxe, traitement de la tuberculose pulmonaire, malade évitable et curable', 1925, Papworth archives, M1:14.

Quoted in Papworth annual report, 1928, p. 7.

Lancet, 1940, i: 131.

10 Manchester Guardian, 27 July 1922.

"Lancet, 1941, i: 198.

12 Pendrill Varrier-Jones, Papers of a pioneer, collected by Peter Fraser, London, Hutchinson, 1943, preface.

${ }^{13}$ R. Y. Keers, Pulmonary tuberculosis: a journey down the centuries, London, Baillière, Tindall \& Cassell 1978, p. 73. Annual report of the Chief Medical Officer to the Ministry of Health for 1919. London, HMSO, 1920, p. 53; National Association for the Prevention of Tuberculosis (NAPT), Handbook of tuberculosis schemes for Great Britain and Ireland, 2nd ed. London, Adlard \& West Newman, 1919.
} 


\section{Linda Bryder}

However, by the First World War, disillusionment was setting in. No cure had been discovered and the results of sanatorium treatment were not impressive. ${ }^{14}$ Papworth Village Settlement was set up at this time of disillusionment with "ordinary" sanatorium treatment. It was heralded as a new and unique solution to the tuberculosis problem. Nevertheless, treatment at Papworth followed established practices and can only be understood in that context. What was different was that Varrier-Jones did not believe tuberculosis could be cured and so his institution was committed to permanent treatment. He was not, however, alone in this belief, nor was he alone in advocating permanent treatment.

Papworth was to become famous in the 1930s as an object-lesson in disease prevention. Emphasis was increasingly placed on maintaining the health of those who resided in the village and on the study of health rather than disease. Yet, it will be shown that this emphasis was not entirely unique; it was shared by at least one other health experiment in the interwar period, the Peckham Health Centre. ${ }^{15}$ The medical ideas underlying these two schemes can also be compared; both were based on an ideology of domesticity, a happy family life being considered integral to the maintenance of health.

Papworth was praised as an ideal village. While it appeared to resemble a village more than an institution, it was nevertheless an institution, sharing features with other institutions and even conforming in some respects to Irving Goffman's model of a "total institution". 16

\section{THE BASIS OF TREATMENT AT PAPWORTH}

Treatment at Papworth was based on a "whole-person" approach to medicine. Varrier-Jones wrote in 1936 that he and Sir German Sims Woodhead (Professor of Pathology at Cambridge University, who supported Varrier-Jones in the early years) "were sure that our scheme would have to aim at treating the whole man or woman, and not merely the diseased portion of that man or woman, and on that basis the Village Settlement scheme has been built."17

Orthodox medicine in the twentieth century has often been described as mechanistic, as concentrating on the diseased organs to the exclusion of the personality of the patient. ${ }^{18}$ Yet in Varrier-Jones's scheme the personality of the

\footnotetext{
14 For example, Dr Halliday Sutherland pointed out at the 1920 Annual Conference of the NAPT that it did appear to be a serious matter that three tuberculosis officers had published in 1920 "perfectly accurate figures in the lay press regarding the results of sanatorium treatment", showing that of all the people who received sanatorium treatment during 1914 approximately eighty per cent were dead by 1920 (Transactions of 8 N.A.P.T. 1920, p. 28).

is Jane Lewis, 'The Peckham Health Centre. "An inquiry into the nature of living" ", Soc. soc. Hist. Med. Bull., June and December 1982: 39-43; Jane Lewis and Barbara Brookes, 'The Peckham Health Centre. "PEP", and the concept of general practice during the 1930s and 1940s', Med. Hist., 1983, 27: 151-161; idem.. 'A reassessment of the work of the Peckham Health Centre, 1926-1951', Millbank Memorial Fund Quart./Health and Society, 1983, 61: 307-350.

${ }^{16}$ Irving Goffman, Asylums. Essays on the social situation of mental patients and other inmates. London, Pelican, 1961.

${ }^{17}$ Tubercle, 1936, 17: 529 (Varrier-Jones's speech at the Tuberculosis Association meeting April 1936).

18 For example, Armstrong argues, following Foucault, that the medical gaze that developed at the end of the eighteenth century, based on the perception of the body as a passive object and related to the introduction of the clinical examination, dominated medicine until the latter half of the twentieth century (David
} 


\section{Papworth Village Settlement}

patient was considered of paramount importance, both in diagnosis and treatment. Regarding diagnosis, Varrier-Jones explained in 1920 how each patient was given a set of questions on arrival at the colony: "the object being to obtain a picture of the man's state of mind and to gain some idea of how the problem presented itself to him". ${ }^{19} \mathrm{He}$ revealed his interest in more than the tubercle bacillus or the infected lung when he devoted a whole chapter in Industrial colonies and village settlements for the consumptive (1920) to the psychology of the tuberculous person. ${ }^{20}$ For his source of the characteristics of the latter, Varrier-Jones read autobiographical accounts by Robert Louis Stevenson and J. Addington Symonds, who had both suffered from tuberculosis. He believed that, while most patients could not express their feelings as clearly as such great writers, they shared common experiences. Therefore, an analysis of the response of the writers would help reach an understanding of other patients. The particular characteristics he discovered included passion and excitability. $\mathrm{He}$ explained that in 1863, Addington Symonds was "no bed-ridden consumptive", yet he was driven by uncontrolled physical and mental impulses: "Some artificial stimulation of the nerve centres can alone account for his restless energy and his no less unnatural depression and fatigue."'21 Varrier-Jones maintained that Symonds's nervous system was periodically and artificially stimulated by the toxic secretions of the tubercle bacillus, thus attributing his psychological state to the disease.

Two medical officers from the Ministry of Health, A. S. MacNalty (later to become Chief Medical Officer to the Ministry of Health) and Nathan Raw, who inspected Papworth in 1920, reported approvingly, "At Papworth the individual case is studied, temperamentally, psychologically, physically, and socially, and there is no mere academic classification of the patient according to his pulmonary physical signs." 22

In treatment too, Varrier-Jones adopted a holistic approach. In 1940, he wrote:

Treat the patient, the whole patient, and his environment as well, and he and his body fluids will conquer his distemper far more surely than any quantity of medical, surgical and Xray apparatus ... I I have used the word person advisedly, for ... we are dealing with persons, not cases, and with that firmly fixed in our minds we shall be more likely to find a solution. In reality those considerations should have the first place in our minds and the medical picture the second. ${ }^{23}$

His adherence to holistic medicine also influenced the kind of research he wished to see carried out. He encouraged research in biochemistry into the "defensive mechanism" rather than the "invading organism", or the tubercle bacillus, the former in his opinion being much more important in the disease process than the latter. Thus in 1933, he supported Edgar Obermer's proposal to study what the latter summarized as the "individual's neuro-endocrine-circulatory-metabolic-adaptational mechanism". ${ }^{24}$ Obermer was described by MacNalty as a "bio-chemist of vivid

\footnotetext{
Armstrong, "The "reappearance" of the sick man in medical discourse 1950-1980", in P. Wright and A. Treacher, The problem of medical knowledge, Edinburgh University Press, 1982, pp. 109-120).

${ }^{19} \mathrm{P}$. Varrier-Jones, Industrial colonies and village settlements for the consumptive. Cambridge University Press, 1920, p. 26; Lancet, 1917, ii: 780.

${ }^{20}$ Varrier-Jones, op. cit., note 19 above, pp. 116-127.

21 Ibid., p. 119.

22 PRO MH52/1, Report by MacNalty and Raw, 20 April 1920, p. 16; P. Varrier-Jones, Lancet, 1941, i: 368

${ }^{23}$ Br. J. Tuberc., 1940, , 34: 94; Lancet, 1941, i: 368.

${ }^{24}$ PRO MH52/10, Obermer's research proposals, 1933.
} 


\section{Linda Bryder}

imagination and somewhat unorthodox scientific views", ${ }^{25}$ and the proposal was rejected. Varrier-Jones complained in 1940 that almost no notice had been taken of his suggestion to research the defensive mechanism. ${ }^{26}$

Varrier-Jones also established a "psychological clinic" at Papworth in 1928, and wrote in his 1930 report that, "This is probably the first time in the history of the treatment of tuberculosis that the mental side has received specific attention". ${ }^{27} \mathrm{He}$ had no faith in chemotherapy. In 1924, he carried out a trial at Papworth at the request of the Medical Research Council on Dreyer's Antigen or Dreyer's Diaphyte Vaccine. He concluded that the antigen had no beneficial effect, but took advantage of the opportunity to initiate a psychological study. He showed the importance of "psychic elements", for patients who thought they were receiving doses of the antigen reported themselves as decidedly better, when in fact none was given. ${ }^{28}$

Nevertheless, Varrier-Jones was not alone in advocating a holistic approach to tuberculosis treatment. Some precedents can be found in the writings of Dr Marcus Paterson, Sir James Kingston Fowler, and Sir Clifford Allbutt. Paterson, Medical Officer of the Brompton Hospital Sanatorium at Frimley from 1905 to 1910 and Medical Director of the King Edward VII Welsh National Memorial Association from 1911 to 1918, wrote in 1911 that he had been trained to diagnose, treat, and give a prognosis in the case of febrile pulmonary tuberculosis by means of the stethoscope alone. He had since come to the conclusion that too much significance had been attached to the local condition, and that not nearly sufficient attention had been given to the state of the blood and the general health of the patient. ${ }^{29} \mathrm{His}$ holistic approach developed from his belief that tuberculosis was a general disease of the blood fluids and not a lung disease; of chief importance, in his opinion, was the patient's resistance to the bacilli and their products. ${ }^{30}$ Sir James Kingston Fowler of the Brompton Hospital was quoted in 1921 as having said, "We place the temperament of the patient first, in order to emphasize the importance which we attach to this factor, and also because we think that hitherto far too little stress has been laid upon it." ${ }^{31}$

Sir Clifford Allbutt, Professor of Physic at Cambridge University and for whom Varrier-Jones had worked at Cambridge from 1910 to 1914, held that there was no such thing as a "case of tuberculosis"; the problem was that of a living personality and not of an inert substance. In pulmonary tuberculosis there was more to be considered than the reaction of the lung tissues to the invading organisms. In his opinion, "the personality, with forces difficult to understand and difficult to contend with" was of the utmost importance. ${ }^{32}$ Varrier-Jones also quoted Allen Krause of the Johns Hopkins Hospital, Baltimore, in 1928, who, in his study on the pathogenesis of tuberculosis, argued that in diagnosis appraisal would approach accuracy only as the






\section{Papworth Village Settlement}

whole person passed under observation. ${ }^{33}$

Actual treatment at Papworth was based first and foremost on fresh air, or "aerotherapy" as it was sometimes known. On arrival, patients were admitted to the hospital section for examination, but were generally quickly transferred to the sanatorium section, which consisted of open-air shelters. One patient recalled that he was allocated a hut under an oak tree and spent two happy years there, "free as a bird, with the wind coming through four canvas flaps on the hut sides, with all the scents of the countryside flowing in - some good, some bad." ${ }^{34}$ Another patient remembered that it was quite common to wake up on a winter morning to find one's boots frozen to the floor ${ }^{35}$ and a nurse recollected how false teeth froze in their glasses. ${ }^{36}$ Patients were, however, supplied with a waterproof blanket to keep the snow off their beds.

Varrier-Jones explained in 1916 that he had demonstrated in his colony in Cambridgeshire that consumptive patients could withstand all the rigours of the changeable English climate, provided that they lived entirely and always in the open-air. He wrote, "What is necessary is as complete a return to Nature, and explicit obedience to Nature's laws as possible." ${ }^{37}$ Others also envisaged the sanatorium as having such a role. For instance, Drs C. H. Garland and T. D. Lister defined a sanatorium as "an institution where patients are treated, practically without drugs, for the cure of their disease. It is essentially a return to Nature ...". ${ }^{38}$

At Papworth, work was part of the treatment. As soon as patients were well enough, they were to work, first for one hour a day, then two, gradually increasing to six when they could apply to live in the village settlement and work full-time. Work, or "graduated labour" as it was commonly known, had already become a routine in many early twentieth-century sanatoriums. For example, at the Brompton Hospital at Frimley the patients built a reservoir in 1908. Such work was supposed to prevent moral degeneration and can be compared with the moral treatment introduced into lunatic asylums in the ninteenth century. ${ }^{39}$ However, in the case of tuberculosis it was given a biological explanation by Marcus Paterson in his theory of auto-inoculation, developed around $1907 . .^{40} \mathrm{He}$ postulated that patients could inoculate themselves by their own tuberculin through controlled physical exertion.

Graduated labour was being practised in many sanatoriums by the First World War. Varrier-Jones's scheme differed in that work in the institution, for at least some of the patients, was to be permanent. It was also to be industrial work, as opposed to

33 Ibid., 1928, p. 23; Amer. Rev. Tuberc., August 1928, 18: no. 2.

34 Frank Durham, personal recollections, Papworth Archives, G2-16.

${ }^{33}$ Papworth Archives, G2-16.

${ }^{36}$ Mrs Goozee, private interview, 25 March 1983.

${ }^{37} \mathrm{P}$. Varrier-Jones, 'Tuberculosis and the working man, an appeal to friendly societies', Cambridge. 1916, p. 9, Papworth Archives, M1-20.

${ }^{38}$ C. H. Garland and T. D. Lister, Sanatoria for the people or the state campaign against consumption, London, Scientific Press, 1911, p. 2.

${ }^{39}$ Andrew Scull, 'Moral treatment reconsidered', in Andrew Scull (editor), Madhouses, mad-doctors. and madmen. The social history of psychiatry in the Victorian era, London, Athlone Press, 1981, pp. $111-115$.

40 J. R. Bignall, Frimley: the biography of a sanatorium, 1979, London, Board of Governors, National Heart and Chest Hospitals, p. 56; Paterson, op. cit., note 29 above, p. 22. 


\section{Linda Bryder}

the farm work adopted by other schemes. ${ }^{41}$ Varrier-Jones was not, however, the only or first person to think of establishing an industrial village settlement or "garden city" for the tuberculous. Hermann M. Biggs of the New York City Department of Health and of the Henry Phipps Institute and vice-president of the National Tuberculosis Association of America, advocated such a colony for arrested cases in 1910,42 as did H. A. Pattison in 1919, who two years later founded and directed the Potts Memorial Hospital in New York, which had a printing department operated by patients. ${ }^{43}$ In England, Varrier-Jones had an ally in J. E. Esselmont, Medical Superintendent of Home Sanatorium, Bournemouth, who published a brochure entitled, Garden cities for consumptives: a national scheme outline in 1913.44 Marcus Paterson also advocated a garden city for the tuberculous in 1920.45

Varrier-Jones and Woodhead wrote in 1917 that their aim at Papworth was to establish a garden city with organized industries in connexion with a central institution. ${ }^{46}$ The influence of the general garden city movement which emerged in the early twentieth century, pioneered by Ebenezer Howard, ${ }^{47}$ is clear. Letchworth Garden City, the product of Howard's ideas, developed along health-conscious lines. The aim of Letchworth was "to combine as far as is practicable the benefits and amenities of rural life with the social and industrial advantages of urban existence so devised as to promote the healthiest possible conditions of life". ${ }^{88}$ The application of this idea to tuberculosis is not difficult to understand, for tuberculosis was widely regarded as an urban disease. Statistics showed that it was more prevalent in cities than in rural areas. In 1919, M. Greenwood prepared statistics showing the death rate from pulmonary tuberculosis for males in 1912 to be 1.11 per thousand in industrial areas and 0.80 in agricultural; the respective figures for females were 0.84 and $0.71 .{ }^{49}$ Not only were the overcrowded and unhygienic conditions of the cities and the undernourishment resulting from low wages held responsible for the excessive tuberculosis in cities, so too were "the restlessness, anxiety, and mental strain which nowadays is so prominent a feature amongst a majority of towndwellers". This was the view of the Chairman of the Joint Tuberculosis Council, S. Vere Pearson, in 1937: "Also the sense of bustle, the noise, and the pace of work in big cities all conduce to irritation and fatigue which ... predispose to tuberculosis." 50 Such views were common and can be related to the anti-urban sentiment which was at its height in the late nineteenth

${ }^{4}$ Sir Robert Philip had established the Royal Victoria Hospital Farm Colony, Springfield, near Edinburgh, in 1910, and Dr N. D. Bardswell set up Kinson Farm Colony, Bournemouth, in 1916. Lancet, 1918, ii: $137-138$.

${ }^{42}$ Transactions of 22 Annual Meeting of National Tuberculosis Association [of America], 1926, p. 336; Varrier-Jones, op. cit., note 12 above, p. 43.

${ }^{43}$ Lancet, 1919, ii: 528; H. A. Pattison, The agricultural and industrial community for arrested cases of tuberculosis and their families, Washington, DC, Federal Board for Vocational Education, 1919.

4 Br.J. Tuberc., 1918, 12: 76; Med. Wld, 7 August 1913.

4s Paterson, op. cit., note 30 above, pp. 196, 197.

46 Lancet, 1917, ii: 785.

${ }^{47}$ Ebenezer Howard, Garden cities of tomorrow, 2nd ed., London, Swan Sonnenschein, 1902.

${ }^{4} \mathrm{H}$. Hyslop Thomson, Tuberculosis and national health, London, Methuen, 1939, p. 103.

9 M. Greenwood, 'Epidemiology of pulmonary tuberculosis', in Chief Medical Officer report for 1919 . London, HMSO, 1920, Appendix 5, p. 330.

${ }^{\text {so }}$ S. Vere Pearson, 'Tuberculosis and city environment', Br. J. Tuberc, 1937, 31: 149-152. 


\section{Papworth Village Settlement}

century but lingered well into the twentieth century. ${ }^{51}$ The idea of a village settlement for the tuberculous had the added appeal that it segregated an infectious group of people from society, important now that the infectious nature of the disease was known. Esselmont, for example, considered this its prime attraction.

The 1919 Inter-Departmental Committee on Tuberculosis among Ex-service Men, chaired by Sir Montague Barlow, recommended that a start should be made by establishing ten such village settlements, each with 200 to 250 patients and their families, throughout the country, and that one million pounds should be allocated by the Exchequer for that purpose. ${ }^{32}$ The Ministry of Health set up a committee to consider the proposal, but it was dissolved following the announcement of the government's economy drive in 1921.

Varrier-Jones's scheme was partly a solution to the after-care problem of the tuberculous, the difficulty the ex-sanatorium patient had in finding a job. But it was envisaged as more than a solution to their financial problems. Varrier-Jones explained the value of his scheme in psychological terms. He wondered how many of his patients working in the industries would "throw up the sponge" if treated as permanent invalids. ${ }^{53}$ In 1935, he described the problem of the unemployed tuberculous person in terms of man's aggressive impulses. These were, he maintained, to be given constructive outlets; if they were not, they would either cause revolution, if turned inward, or war, if directed outward. Such impulses were not, in his opinion, confined to tuberculosis sufferers, but the latter, through being unemployed, were particularly susceptible to them. He asked, "How many revolutionaries has the medical profession made through not providing constructive outlets for the energies of the tuberculous, through neglecting sociology and concentrating on pathology?"s4

The industries established at Papworth included carpentry, joinery, cabinetmaking, poultry farming, bootmaking and repairing, tailoring, portmanteau and attaché-case making, printing, horticulture, sign-writing, and handmade jewellery. Papworth Industries soon became a very successful enterprise, expanding from a turnover of $£ 410$ in 1918 to $£ 85,000$ in 1930 , to over $£ 100,000$ in 1938. Varrier-Jones showed great business skills in organizing the sale of the produce. He contracted with the large department stores in London, and persuaded the Ministry of Health to inform him when they sanctioned a loan for the building of a local authority sanatorium so he could bid for a contract to supply the furniture. Papworth became a truly commercial enterprise, which distinguished it from small craft industries. Varrier-Jones stressed the value of mechanization: he did not romanticize about a return to cottage industries. For psychological reasons, as well as financial, VarrierJones considered it important for Papworth to be a successful commercial enterprise and not dependent on charity.

\footnotetext{
31 John Nelson Tarn, Five per cent philanthropy: an account of housing in urban areas between 1840 and 1914. Cambridge University Press, 1973, p. 153.

32 Report of the Inter-Departmental Committee Appointed to Consider and Report upon the Immediate Practical Steps which should be Taken for the Provision of Residential Treatment for Discharged Soldiers and Sailors Suffering from Pulmonary Tuberculosis and for their Re-Introduction into Employment. Especially on the Land, London, HMSO, 1919, Cmd 317, pp. 13, 15.

s3 Papworth Annual report, 1923, p. 16.

s4 Ibid., 1935, p. 19.
} 


\section{Linda Bryder}

In 1931, an average of 294 workers, all patients, were employed daily. For the first two months the patient earned nothing: apparently his working capacity was being tested. In the third month he earned three pence an hour, in the fourth month four pence, and in the fifth month five pence. After that, he would graduate to the village settlement through a rigid selection process dependent upon accommodation availability, when he would be employed at trade union rates of pay.

A skilled instructor or foreman was placed in charge of each department, and Varrier-Jones considered it to be of paramount importance that this instructor should be an ex-patient. He claimed to have had several failures when healthy instructors had been employed, and he attributed this primarily to the lack of appreciation, on the part of the instructor, of the psychology of the patient. He believed that no healthy man could understand the condition of the consumptive; that no amount of teaching could bring home to him the differences between incapacity for work and shirking or malingering. But if the instructor had himself suffered from the peculiar nervous or physical fatigue produced by the disease, and had through a course of treatment been shown how to recover from it, he was ready to appreciate the phenomenon when he next met it.ss

Work was not the only component of Varrier-Jones's treatment. Family and community also played an important role. He opposed institutions, claiming they had a detrimental psychological effect on the patient. In his opinion, "Institutional treatment, separating the patients as it did from their families and imposing upon them utterly unnatural restrictions" was wrong. ${ }^{56}$ The advantages of settling a patient in a village with his family were, he believed, immense: "He can look the future in the face; he has hope; he has independence; he has position; he has authority. The environment is his home - a wonderful thought; home with all its associations, something to work for, not an institution in which he is 'placed' or to which he is 'sent'. He has a sense of security .... I am convinced that it is his mental outlook ... that makes for success, nay, is success." 37 Thus the family model Varrier-Jones envisaged for his village settlement was patriarchal - a tuberculous man, his wife, and children. His ideology was firmly rooted in the cult of domesticity. The private sphere was important, that "privacy ... so dear to the heart of an Englishman".s8

The cottages at Papworth were semi-detached, two storeyed, with three bedrooms, and a verandah on the first floor for the tuberculous patient. Windows were to be permanently open. Ornaments and wallpaper were forbidden because they collected germs (an indication that, despite his emphasis on resistance rather than infection, he still considered germs important in tuberculosis causation). Each cottage had its own garden. In 1918, there were eight cottages, by 1928, 100, and by 1938, 142. In 1938, there were 600 settled in the village, giving Papworth a total population of 1,000 when 400 patients, staff, and their families were included. During the period 1918 to 1938 ,

ss PRO MH52/1, Report by MacNalty and Raw, 20 April 1920, p. 5; PRO MH52/3, visit to Papworth by W. M. Clark et al., 6 October 1930.

s6 National Insurance Gazette, 11 October 1919 (speech before the Leicestershire Insurance Committee).

${ }^{57} \mathrm{Br} . J$. Tuberc., 1926, 20: 15.

ss Lancet, 1918, ii: 136. 


\section{Papworth Village Settlement}

205 ex-patient families resided in the village; in 1938, there were 142 families with 368 children..$^{99}$

By 1927, Papworth was described as an independent community. It had a school house, a post office, a parish church and non-conformist chapel, recreation rooms and cinema, two stores, and a public house. A new hall was built in 1929 for village meetings, dances, dramatic entertainments, and a weekly cinema performance (talkies arrived in Papworth in 1932). An open-air swimming-pool was installed in 1930. Referring to the social activities of the settlement in his 1923 Report, Varrier-Jones wrote: "I am again faced with the impossibility of describing adequately the life and times of a small country town. Sports clubs (tennis, cricket, and golf), social activities such as Amateur Dramatics and Horticultural Society, Women's Institute, Boy Scouts, educational and religious activities, all have their own workers, secretaries, and committees...."60

The Daily Mail reported in 1926 that the community at Papworth enjoyed "the simple pleasures of country life", pointing out that Papworth had won the local cricket championships the previous year. The flower show to be held the following week was "a burning topic of conversation", for there were two cups to be won. ${ }^{61}$ In 1927, the Papworth Athletic Club was founded. The 1933 annual report referred to the billards and snooker league, the West Cambridgeshire Cycling Club, folk dancing, the Papworth Everard Tennis Club, Papworth Industries Cricket Club, South Parks Recreation Club, a Christian Group, Papworth Everard British Legion, St John's Recreation Club, Papworth Sick Club, and St Peter's Book Club.

\section{THE EMPHASIS ON HEALTH MAINTENANCE AT PAPWORTH}

In placing such emphasis on family and community life, the Papworth scheme had much in common with the Peckham Health Centre. The founders of Peckham in 1926, G. Scott Williamson and Innes Pearse, like Varrier-Jones, believed that the key to health lay in the process of interaction between people and their environment, and that indicators of health should therefore include evidence of the growth of personality and family integration, that is, the degree of success the individual achieved in homemaking and building inter-personal and family relationships. ${ }^{62}$

It is clear, however, that the comparison should not be taken too far. By the nature of his scheme Varrier-Jones dealt with a different group of people from Williamson and Pearse, who excluded the poor, the old, and the unemployed, and whose views approached those of the eugenicists. At first glance, it might appear that Papworth was an attempt to weed the tuberculous out of society, but Varrier-Jones, in fact, stressed that his scheme was not based on eugenicism. He pointed out that, "It is often argued that tuberculosis is the great means adopted by nature to weed out the unfit. Such a statement is grossly inaccurate... Recently, making a careful examination of

\footnotetext{
${ }^{39}$ E. M. Brieger, The Papworth families. A twenty-five years' survey, London, Heinemann Medical Books, 1944, p. 74.

oo Papworth Annual report, 1923, p. 24.

61 Daily Mail, 15 July 1926.

62 Lewis (1982), op. cit., note 15 above. Peckham was closed in 1930 but reopened in 1935.
} 


\section{Linda Bryder}

the histories of all the patients admitted to the Colony, it was a matter for surprise to find how high was the percentage of men who had led an athletic life before they were attacked by the disease." ${ }^{63} \mathrm{He}$ maintained that amongst soldiers discharged from the army suffering from pulmonary tuberculosis, it was exceptional to find that those who were admitted for treatment were those who were placed by the Recruiting Medical Boards in Grade III. In his opinion, "the disease is no respecter of persons ... it exercises no selective principles and ... weak and strong alike fall prey to the disease. If it be our object to perpetuate a race of physically strong individuals ... then it is useless to... [focus on] a disease which is non-selective, ie attacks the well-developed muscular man as it does the weak, nay even in greater proportion."64

He also believed that this applied to the intellect; that there was no special susceptibility of the feeble. He was indignant in 1932 when some researchers into mental deficiency and tuberculosis wanted to come to Papworth to see whether the children at Papworth were subnormal intellectually. He replied, "all the children born in the village.... are quite sane."6s Thus Varrier-Jones's aim was not to establish a "leper colony", but to make the tuberculous as self-supporting as possible, restore their self-respect and happiness, and make them useful, healthy, and contented members of society.

His scheme also differed from Peckham in having a less sophisticated, scientific theoretical framework for his health philosophy. Both believed in the importance of family and community in health maintenance, but Williamson and Pearse couched this belief in biological terms whereas Varrier-Jones expressed his reasons much more practically. In his opinion, the state of mind of the individual was important in health maintenance and a happy family life produced a healthy state of mind.

Varrier-Jones was less concerned with the scientific theoretical basis of his treatment and the implications to his professional status than J. B. McDougall, the Medical Superintendent of the other major village settlement in England, Preston Hall, ${ }^{66}$ who was clearly worried about the prospect of being classified as an industrial administrator. He wrote in 1927 , "I do not share for one moment the view that a special business experience outside the medical world is even desirable. Occupational therapy is a form of treatment, it is not a business. What is required . . is a thorough grasp of the principles underlying occupational therapy, and in this respect it differs in no way from any other form of treatment for tuberculosis or any other diseases." $67 \mathrm{He}$ equated the knowledge required by physicians inducing collapse of the lung and by surgeons with that required by practitioners of occupational therapy. ${ }^{68}$ Varrier-Jones revealed no such concerns. On the contrary, he believed that "it would be an excellent thing if no student were accepted at any hospital until he could prove that he had earned his living for at least one year in some lay occupation. In that year he would

\footnotetext{
${ }^{63}$ Varrier-Jones, op. cit., note 19 above, pp. 83-96.

64 Ibid., p. 85.

6s PRO MH52/3, Varrier-Jones to MacNalty, 25 October 1932.

${ }^{66} \mathrm{See}$ below for further discussion of Preston Hall.

${ }^{67} \mathrm{Br}$. J. Tuberc., 1927, $21: 86$.

68 Ibid., p. 87.
} 


\section{Papworth Village Settlement}

learn nothing about biology, but he would learn a great deal about life". He thought that was especially desirable in relation to tuberculosis. ${ }^{69}$

However, if the similarity between Papworth and Peckham in the methods of health maintenance and the philosophy underlying those methods can only be seen in general terms, there is another respect in which they were very similar: both were regarded by their administrators as health experiments. Williamson and Pearse designed Peckham Health Centre as a human laboratory, where they planned to investigate the nature of health and the conditions necessary for its maintenance; likewise, Varrier-Jones planned to use Papworth as an opportunity to study tuberculosis and its prevention, asking in 1940, "Is there any field which provides the same unique opportunity for studying the mechanism of resistance as a Village Settlement? Where else can be found hundreds of tuberculous persons and their contacts, living under observed conditions and in a known environment, not for months but for years at a time?"70 Such experimentation was, in his opinion, far more important than the work carried out in the pathology department.

Meticulous records on the health of the community, and particularly the children, were kept by the medical officer, Dr Leonard Stott. He held a weekly child clinic at which minor ailments were dealt with and periodical medical examinations of every child were made. A continuous record of the physical conditions and state of health of each child was kept, and Dr Stott observed in 1929, "We know our children both outside and in". ${ }^{11}$

In 1934, Dr E. M. Brieger was appointed to investigate the health of Papworth, in particular its children. He had formerly been Medical Director of Breslau Municipal Hospital and Tuberculosis Colony and a lecturer in Clinical Medicine and Tuberculosis at the University of Breslau. His study, financed by the Medical Research Council, was published in 1944. Of the 260 children admitted to Papworth, five had juvenile tuberculosis and nine developed tuberculosis of the adult type (all were over ten years of age at the time of admission). None of the 108 children born in the village, while a member of the community, developed tuberculosis in any form. ${ }^{72}$

The reasons given by Varrier-Jones for the absence of clinical disease in the children of Papworth in 1927 were often quoted. They included the favourable social, economic, and psychological conditions, as well as the enlightened attitude of the inhabitants towards health and disease prevention. ${ }^{73}$ The health lessons of these results were considered significant. In 1957, F. R. G. Heaf, Professor of Tuberculosis in the University of Wales, wrote of the Papworth experiment: "This influence of living conditions on the incidence of tuberculosis is an object lesson to all seeking to eradicate the disease from our towns and cities."74 "Papworth principles" were not only a

\footnotetext{
69 Ibid., 1940, 34: 96-97.

70 Ibid., p. 99.

" PRO MH52/3, 18 September 1929.

72 Brieger, op. cit., note 59 above, p. 147.

${ }^{73}$ George Newman, Chief Medical Officer report for 1933, London, HMSO, 1934, p. 139. A. S. MacNalty, preface to Papworth families, op. cit., note 59 above, p. ix.

74 F. R. G. Heaf, 'Rehabilitation', in F. R. G. Heaf (editor), Symposium of tuberculosis, London, Cassell, 1957, p. 696.
} 


\section{Linda Bryder}

safeguard against tuberculous infection but also non-tuberculous diseases, for the health record of the Papworth children in general was impeccable. There had been two deaths among them; one was run over by a motor vehicle and the other died of diphtheria. The final measure of their physical fitness was the proud boast that approximately fifty of them fought in H.M. Forces in the Second World War. ${ }^{75}$ The film made on Papworth in 1943 concluded by focusing on the children, with these words: "In these youngsters we have the final results of a courageous enterprise", 76 thus stressing the preventive aspects of the Papworth experiment above the curative.

\section{PAPWORTH AS A "TOTAL INSTITUTION"}

In emphasizing family and community, Varrier-Jones tried to play down the institutional nature of Papworth. Nevertheless, it was an institution, indeed, in certain respects a "total institution" on the Goffman model.

An essential feature of total institutions was their isolation from wider society and barriers to departure built into the physical plant, such as locked doors, high walls, barbed wires, cliffs, water, forests, or moors." Papworth did not have locked doors; it was not a prison, although it was described as such by an ex-service man in 1921 . Patients were restricted in their movements but settlers and their families were not, in theory at least. However, it was no mere coincidence that the site on which Papworth was founded is an isolated one. ${ }^{78}$ Varrier-Jones explained to MacNalty and Raw in 1920 that its isolation was an advantage because settlers were encouraged to seek recreation and leisure occupations within the precincts of the community and were not tempted to frequent the cinema and public house in a neighbouring town. ${ }^{79}$

Like all institutions it had rules, but the discipline at Papworth was to be first and foremost self-discipline. Each patient was issued with a booklet with instructions: "You are admitted a member of the Colony on the distinct understanding that you will always behave like a Gentleman. You are put on your honour to do the right thing, because it is the right thing, and not from fear of punishment .... It is up to you to make the treatment a success." regarded as under treatment.) Thus the responsibility was placed on the patients themselves. Self-discipline and self-direction were seen as the keys to successful treatment, just as the moral treatment of lunatic asylums aimed at encouraging the individuals' own efforts to reassert their powers of self-control. The Papworth annual, a journal for the settlement, also aimed to encourage self-control, and selfimprovement; for example, patients were asked to present essays for publication entitled, "Why I am an optimist".

Self-discipline was therefore encouraged, but external discipline was still regarded as important and even necessary. The settlers were not only supervised during working

${ }^{75}$ N.A.P.T. Bull., April 1945: 5.

${ }^{76}$ Film on Papworth Village Settlement, 1943, British Film Institute Archives.

"Goffman, op. cit., note 16 above, pp. 15, 16.

78 Papworth Village Settlement was situated in the Caxton and Arrington Rural District of Cambridgeshire, twelve miles distant from Cambridge, six miles from Huntingdon, and six miles from St Ives.

79 PRO MH52/1, MacNalty and Raw report, 20 April 1920, p. 1.

${ }^{80}$ 'Advice to patients', Papworth Archives, L. Gen. Info. 1-8, 592. 


\section{Papworth Village Settlement}

hours. Describing the new hall in 1929, MacNalty noted that Varrier-Jones supervised the frequency, length, and character of the entertainments "in the interests of the village settlement".81 In 1922, Varrier-Jones wrote that the tuberculous person's "whole life, waking, working, sleeping and all the manifold activities of existence [should] be carefully guarded and guided". ${ }^{22}$ These views were not so different from those of Marcus Paterson at Frimley. Paterson had strictly supervised and controlled all activities as part of his treatment based on the "auto-inoculation" theory, to the extent of censoring mail in case it upset the patient. ${ }^{83}$

Varrier-Jones was supported in his beliefs on the importance of discipline by his senior staff, Dr Stott, the chief medical officer, and Miss Kate L. Borne, the matron. Stott was described by a patient as a disciplinarian but fair. ${ }^{84}$ That Borne took a strict line concerning the importance of regulating social activities is evident from her speech on the causes of tuberculosis among young women, delivered at the 1933 Annual Conference of the National Association for the Prevention of Tuberculosis. She held that the increasing sense of independence of young women after working hours, involving exhausting pleasures and restricted hours of rest, lowered a resistance that was already in danger of being over-taxed, with a subsequent breakdown. ${ }^{85}$

In 1974, R. Parker, gave a good indication of the role of the senior staff under Varrier-Jones:

Dr Stott's eagle eye was everywhere, looking for infringements of the rules concerning late hours, restrictions on travel, etc. He would pedal around on his bicycle, see the bus about to set off for Cambridge, and if there was anyone on it who should not have been there, the beckoning finger was all that was needed to remove him. Likewise in the cinema; lights on; there stood the Doctor and the Matron, scanning the rows; you, you, and you, off to bed you go." The culprits grinned sheepishly, got up at once and off they went to bed. There was inevitably a certain amount of backsliding, a bit of "trying it on", but the discipline on the whole was marvellous. "Fatherly" was how the patients described it, "If he told you to do something you did it". "We feared him but we loved him"... ."

Varrier-Jones was popularly known in the settlement as "the old man". ${ }^{87} \mathrm{He}$ envisaged his role as much more than an administrator; he saw himself as a paternal figure and perhaps could best be described as a benevolent dictator over the community. J. B. McDougall wrote of him, "From the inception ... he remained in supreme control, dictating policy to the minutest detail". ${ }^{88}$ The Western Mail wrote of Papworth in 1922, "In the centre of this delightful little community village is Papworth Hall, where $\operatorname{Dr}$ Varrier-Jones ... controls his little community.... Perhaps the happiest man in the whole village is Dr Varrier-Jones who takes tremendous pride in what may be termed his own community." ${ }^{89}$ Just as

"PRO MH52/3, A.S. MacNalty, 25 June 1929.

32 J. State Med., May 1922, 30, no. 5: 90.

23 Paterson, op. cit., note 29 above, p. 39.

a Frank Durham, personal recollections, Papworth Archives, G2-16.

ss K. L. Borne, 'The part played in the production of tuberculosis by environmental conditions', Transactions of 19 Annual Conference N.A.P.T., 1933, p. 157.

${ }^{86}$ Rowland Parker, On the road. The Papworth story, Cambridge, Pendragon Press, Papworth Industries, 1977, p. 147.

"7 Frank Jordan, interview, 23 March 1983. 'History of the trunk making department 1921-59', Papworth Archives, G1.

sancet, 1941, i: 198.

3o Western Mail, 16 August 1922. This possibly gives a clue to Varrier-Jones's own motivations. While he 


\section{Linda Bryder}

Varrier-Jones could be described as paternal or even patriarchal, so the patients can be seen as role-playing; they responded accordingly in a child-like manner, as is evident from the description above. Neither are there any indications that they were an exceptionally docile or unusually amenable class of people. Such role-playing was not, however, uncommon in tuberculosis as well as other types of institutions. ${ }^{90}$

While inmates in institutions typically have restricted external contacts, staff often operate on an eight-hour day and are socially integrated into the outside world. ${ }^{91}$ In this respect Papworth differed: Varrier-Jones wanted or expected total involvement of staff as well as patients in the community.

Miss Borne fits the classic stereotype of a matron in the Nightingale tradition. Miss Robinson, who succeeded her as matron in 1943, described her almost fanatical dedication to her profession, a dedication which she expected her nurses to share, and which, according to Robinson, they did. "She never expected you to go off duty. Just when you thought you were going off duty, she would decide to get some laundry done, or a store-room tidied up. She herself worked like a man." ${ }^{92}$ Even retired nurses continued to live in the settlement in a hostel built for that purpose in 1932, though Borne herself left after Varrier-Jones died. Many of the nurses came as patients; it was claimed in 1943 that all the thirty nurses then working there had previously had tuberculosis (a large number of nurses with tuberculosis working in sanatoriums was not, however, uncommon $\left.{ }^{93}\right) .94$

As we have seen above, Varrier-Jones preferred to employ tuberculous industrial instructors because of their more empathetic attitude towards the patients. Possibly more important than such sympathy was their commitment to the institution itself. Varrier-Jones wrote of the healthy instructor: "The Village Settlement means nothing to such a man, can have no meaning. It is not his home; he is only a member of the staff of an institution .... With a mental outlook of this kind, success can never be attained ... the spirit which pervades the whole community, the earnest desire, the right direction of hope - these are the foundation stone and the motive force of the Village Settlement."9s Thus Varrier-Jones expected total involvement from the staff as well as patients. Significantly, all enumerations of the population of Papworth included patients and staff indiscriminately; it is very difficult, if not impossible, to

believed that tuberculosis was a "social disease" which could strike anyone at any time, he did not become involved in social reform movements outside Papworth. He was apparently apolitical, and was totally preoccupied with the Settlement and with increasing its (and perhaps his own) prestige and fame.

${ }^{9}$ Otto Walther, one of the pioneers of sanatorium treatment in Germany in the nineteenth century, was described as an autocrat. M. Paterson at Frimley and his successor, R. C. Wingfield, were described as autocratic, as was J. B. McDougall at Preston Hall. These examples can be multiplied. For an example in another type of institution, see Nancy J. Tomes, 'A generous confidence: Thomas Story Kirkbride's philosophy of asylum construction and management', in Scull (editor), op. cit., note 39 above, p. 136. Williamson at Peckham was also described as a dictator.

${ }^{91}$ Goffman, op. cit., note 16 above, p. 18.

92 Parker, op. cit., note 86 above, p. 149.

${ }^{93}$ For example, Dr Esther Carling of Peppard Common Sanatorium wrote that at times a third of their regular staff had suffered from tuberculosis (Tubercle, July 1937, 18: 456).

${ }^{94}$ Papworth Film, 1943. MacNalty reported in 1936 that forty-three nurses at Papworth had been sanatorium patients. Chief Medical Officer of Health report for 1936, p. 98.

${ }^{93}$ Br.J. Tuberc., 1926, 20: 16. 


\section{Papworth Village Settlement}

form an accurate impression of their respective numbers.

Ceremonies and visits from outsiders, Goffman suggests, play an important role in institutions in binding patients and staff. ${ }^{96}$ Such occasions abounded at Papworth. The 1924 Papworth Christmas annual recorded one social occasion: "The Merriest, Maddest Day of 1924 - the day on which we held our Flower Show and Fete". It was maintained that on that day Papworth was the liveliest and most important place in Cambridgeshire, and that over 5,000 people had passed though the gates by 5.30 p.m. ${ }^{97}$ Such activities and the related publicity led to a sense of pride among the inhabitants. Sir Percival Philips wrote of Papworth in 1926, "Tucked away in the fields of a quiet Cambridgeshire lane is an industrious little community which was described to me by one of its proud members as 'the happiest village on earth'."98

As in other institutions, inmates did develop their own social life independent of those in authority ("hospital underlife", in Goffman's words"9), for example, patients married nurses (including a suicide pact between a patient and a nurse ${ }^{100}$ ), despite the prohibition on their socializing. However, the evidence suggests that the discipline was greater than in most other institutions. Several factors may have contributed to this. First, there was the patients' sense of gratitude for being saved from the fate of tuberculosis sufferers in the "outside world"; a fear not infrequently mentioned by patients in the Papworth annual (Papworth was described by more than one patient as a haven). There was also the publicity and consequent sense of pride in participating in "the most successful socio-medical experiment of our times". ${ }^{101}$ Third, amenities were available which neighbouring villages lacked. Finally, only a small proportion of patients were privileged enough to become settlers. As Sir Percival Philips pointed out, all patients passed through "probationary stages under the keen eye of $\mathrm{Dr}$ Varrier-Jones, ... who judges them as men as well as in the character of patients". ${ }^{102}$ Of the 1,778 patients admitted from 1917 to 1926,123 became settlers, or 6.9 per cent. ${ }^{103}$

The majority of patients, therefore, returned to society after a short stay. It was pointed out that not all patients would choose to live permanently in such a village settlement. Parker suggests the reason for this: "Not everyone is fitted for life in Utopia." 104 The patient at Papworth was, he believed, not a case in a hospital but "a human being who can live a full life, so long as he stays in his environment which is deliberately arranged so that he will want to stay in it, being a sensible chap." ${ }^{105} \mathrm{He}$ pointed out that the patient's leisure time was spent in his garden, he enjoyed the entertainment available, a library was placed at his disposal, and there were popular and entertaining lectures. Parker added in parenthesis, "Of course, if he does not

${ }^{96}$ Goffman, op. cit., note 16 above, pp. 89-105.

97 Papworth Christmas annual, 1924, p. 6.

98 Daily Mail, 15 July 1926.

99 Goffman, op. cit., note 16 above, pp. 157-280.

100 Daily Mail, 28 May 1938.

${ }^{101}$ The Times, 8 July 1927.

102 Daily Mail, 15 July 1926.

${ }^{103}$ PRO MH52/3, report of a visit to Papworth by W. M. Clark and others, 6 October 1930; McDougall, Br. J. Tuberc., 1930, 24: 86.

104 Parker, op. cit., note 86 above, p. 146.

105 Ibid., p. 143. 


\section{Linda Bryder}

consider that he is 'living' unless he can spend three hours in a pub every night, follow his favourite football team, wherever they go, see the bright lights of the city once a week, smoke as much as he wants to - Papworth is not for him." ${ }^{106}$ However, the patients still living at Papworth, did not see it in those terms, ${ }^{107}$ but as a chance to earn their living, which they did not feel they would have "outside". Their reasons for preferring to remain in the village were primarily economic, although, as Goffman points out, prolonged residence in an institution does lead to a dependency upon that institution; ${ }^{108}$ subconsciously, there may have been a fear of leaving Papworth, a fear of the "outside world".

Varrier-Jones maintained that there was always a long list of applications for settling in the village, and constant expressions of disappointment at rejection, which was necessitated by lack of space as accommodation expanded only slowly. The first female patients were admitted to Papworth in 1923 and a hostel was opened for them to remain and work in the factories in 1926. Female patients, however, could not bring their families to settle in the village. ${ }^{109}$

Given the choice, Varrier-Jones would have kept the majority of patients (apart from married women and any undesirable types) there permanently. A limiting factor was that local authorities, who were responsible for paying many of the patients' maintenance costs, were only prepared to make payments for a short period, rarely exceeding six months. Thus only those who could support themselves by working in the industries could stay beyond that period. Arrangements were made with some local authorities whereby if the patient relapsed after working in the industries, the local authority would resume the payment of maintenance costs despite the fact that the patient had not been residing in the authority's area prior to the relapse. Some of the patients were ex-service men on pensions. They received full pension for the first year and then the pensions were reduced according to their disability, or the amount they earned. The matron also started a welfare fund for those employed in the factories who had to take time off through illness, and all workers were insured.

Lack of space in the settlement was the main limiting factor for those who were well enough to work. Similarly, the Medical Superintendent of Preston Hall found patients to be disappointed when they could not remain and work in the factories. ${ }^{110}$

\section{A MODEL FOR OTHER INSTITUTIONS}

Despite the great enthusiasm for Papworth, few similar institutions were established. Those in England included Preston Hall in Kent, set up in 1920 but remodelled on Papworth lines in 1925; Barrowmore Hall in East Lancashire, 1921; Wrenbury Hall in Cheshire, 1922; and Sherwood Forest Settlement near Mansfield in Nottinghamshire, 1933. All these settlements except Preston Hall were very small; while Preston Hall had a population comparable in size to Papworth in the 1930s,

\footnotetext{
106 Ibid., p. 143.

107 Private interviews, 23-25 March 1983.

106 Goffman, op. cit., note 16 above, p. 62.

109 Widows of patients and their families were not permitted to stay.

${ }^{110}$ Appendix to Medical Director's report, July 1927, unpublished memorandum on the selection of patients as settlers, Preston Hall, Kent.
} 
Barrowmore had a village population of eighty-five in 1948, Wrenbury Hall had thirty-five colonists in 1943, and Sherwood Forest had twenty in 1939. There were also some even smaller "colonies": Stanninghall Colony near Plymouth in Norfolk provided permanent employment for eight settlers; Effort Colony near Plymouth, seventeen settlers; Wooley Settlement in Northumberland, ten settlers. Preston Hall differed from Papworth in one aspect: tenancy in the village was for five years only, thus destroying what Varrier-Jones considered an essential part of treatment at Papworth, security.

The most important reason for the failure to establish other schemes on the Papworth model, despite all the enthusiasm, was financial. The two schemes of appreciable size, Papworth and Preston Hall, were financed by voluntary sources and even the small settlements of Barrowmore Hall and Wrenbury Hall were dependent initially on such sources. The Ministry of Health approved of Papworth and even gave it grants amounting to $£ 48,880$ by 1929.111 They advocated the establishment of other settlements on the Papworth model and set up committees to investigate the possibilities in 1920 and 1929; yet they were not prepared to finance them. Institutional treatment for tuberculosis had become in 1921 the statutory obligation of local authorities, some of which expressed interest in establishing such a village settlement. Yet, as Varrier-Jones pointed out, to be successful, such a scheme had to be carried out on a large scale. Most local authorities were not large enough themselves to finance a village settlement, and jealousy between local authorities, and even within the same counties, prevented combined efforts. For example, Sherwood Forest was situated a short distance from the Nottingham and Nottinghamshire Sanatorium, and Barrowmore Hall a short distance from the Cheshire Joint Sanatorium, but in neither case was there any attempt to amalgamate. Thus the only successful schemes were Papworth and Preston Hall, the latter administered by the British Legion, the former dependent upon Varrier-Jones's business acumen and fund-raising abilities.

\section{CONCLUSION}

To regard Papworth as a unique experiment therefore overlooks the features it shared with other tuberculosis institutions, the way in which it developed out of established treatments in tuberculosis institutions and ideas widely supported at the time of its inception. Treatment, as in other tuberculosis institutions, was based on fresh air and graduated labour. The main difference was that Papworth was committed to permanent treatment, at least for some patients. In some respects, Papworth continued to conform to established practices, for instance, developing artificial pneumothorax and chest surgery in the late 1920s and 1930s. Varrier-Jones boasted in 1933 that the thoracic unit would give Papworth "what is believed to be the most complete scheme for the treatment of tuberculosis that exists anywhere". ${ }^{112}$ However, he did not regard surgical intervention of great value, nor was it a feature for which the institution was renowned. Much more important was the emphasis on disease preven-

11 PRO MH52/3, 13 October 1932, Ministry of Health memo for Minister’s visit to Papworth. $£ 38,880$ had been given in aid of the provision of the hospital and $£ 10,000$ towards the erection of twenty-five cottages.

112 Papworth annual report, 1933, p. 15; Tubercle, January 1935, $16: 182$. 
tion that developed at Papworth in the 1930s, an emphasis which it shared with the Peckham Health Centre. As an institution, despite Varrier-Jones's attempts to play down that aspect and emphasize its resemblance to a village, it conformed in broad terms to Goffman's model of a "total institution". Papworth Village Settlement was unique in one respect - it was a great financial success, a tribute not to Varrier-Jones's original thought but to his administrative abilities and business acumen. However, Papworth enjoyed widespread fame, and it is clear that, despite the limited number of tuberculosis patients who benefited from the scheme, it captured the imagination of the day.

\section{ACKNOWLEDGEMENTS}

I am grateful to Mr Frank Jordan, Mr H. and Mrs D. Huffer, Mr N. and Mrs D. Langdon, and Mrs Goozee of Papworth Everard, Cambridgeshire, and the late Dr Walter Pagel, for relating to me their impressions of Papworth Village Settlement under Sir Pendrill Varrier-Jones. 